\title{
The importance of the new prognostic scoring system for evaluating patients with lower-risk myelodysplastic syndrome at diagnosis
}

\section{Importanța noului sistem de scor prognostic în evaluarea pacienților cu sindrom mielodisplazic cu risc scăzut la diagnostic}

\author{
Aurelia Tatic ${ }^{1,4 *}$, Cerasela Jardan ${ }^{1,4}$, Otilia Georgescu ${ }^{1}$, Oana Stanca ${ }^{2,4}$, \\ Madalina Vasilica $^{1}$, Sorina Badelita ${ }^{1}$, Ana Manuela Crisan ${ }^{1,4}$, Adriana Colita ${ }^{1}$, \\ Dan Colita ${ }^{1}$, Genica Vulcan ${ }^{3}$, Anca Roxana Lupu ${ }^{2,4}$, Ionel Iosif ${ }^{5}$, Daniel Coriu ${ }^{1,4}$ \\ 1. Center of Hematology and Bone Marrow Transplantation, Fundeni Clinical Institute, Bucharest, Romania \\ 2. Hematology Department, Coltea Hospital, Bucharest, Romania \\ 3. Hiperdia, Brasov, Romania \\ 4. University of Medicine and Pharmacy "Carol Davila", Bucharest, Romania \\ 5. National Centre for Prevention and Diseases Control, Bucharest, Romania
}

\begin{abstract}
Myelodysplastic syndromes (MDS) are a group of heterogeneous clonal stem cell disorders characterized by ineffective hematopoiesis with dysplastic changes in one or more myeloid cell lines and increased risk of progression to acute leukemia. The current diagnosis criteria include the morphology of peripheral blood (PB) and bone marrow (BM), bone marrow biopsy and cytogenetic exam. Material and method. For this study, we have analyzed 33 patients diagnosed with lower-risk MDS (IPSS 0 and intermediate-1) according to the World Health Organization (WHO) classification (2001) between 2008 and 2012. The diagnosis was confirmed by blood cell counts, bone marrow (aspirate and biopsy) exam and cytogenetic exam. Other causes of cytopenia or dysplastic changes were excluded. Results. The types of MDS according to the WHO classification were: nine patients with refractory anemia (RA) (27.27\%), sixteen patients with refractory anemia with ringed sideroblasts (RARS) (48.48\%), and eight patients with refractory cytopenia with multilineage dysplasia (RCMD) (24.24\%) out of which two with refractory cytopenia with multilineage dysplasia with ringed sideroblasts $(R C M D-R S)$. Cytogenetic exam was performed in all patients, but analyzable metaphases for cytogenetic exam were obtained only from twenty five patients. The patients who did not have analyzable metaphases on cytogenetic exam were considered low risk if: they had only one cytopenia and the percent of bone marrow blasts was less than 5\%. For all patients who had analyzable metaphases at cytogenetic exam, the International Prognostic Scoring System (IPSS) and Revised International Prognostic Scoring System (R-IPSS) scores were determined, and their survival and the death leading events were observed. According to IPPS (1997), the cytogenetic exam was good in 17
\end{abstract}

*Corresponding author: Tatic Aurelia, MD, "Carol Davila” University of Medicine and Pharmacy; Hematology and Bone Marrow Transplantation Department, Fundeni Clinical Institute, no.258, Fundeni street, sector 2, zip code: 022328. Phone: +40213180423, E-mail: auratatic@yahoo.com, Bucharest, Romania. 
cases, intermediate in 1 case and poor in 7 cases. The IPSS score was low in 13 cases and intermediate-1 in 12 cases. According to R-IPSS, cytogenetic exams had been very good and good in 17 cases, intermediate in 1 case, poor in 6 cases and very poor in 1 case. R-IPSS was very low and low in 17 cases and intermediate and high in 8 cases. Conclusions. This new R-IPSS score at diagnosis allows a more accurate classification of patients into risk groups and thus enables risk adapted therapy.

Keywords: myelodisplastic syndromes, International Prognostic Scoring System (IPSS), Revised International Prognostic Scoring System (R-IPSS)

\section{Rezumat}

Sindroamele mielodisplazice (SMD) reprezintă un grup heterogen de hemopatii clonale ale celulei stem caracterizate prin hematopoieză ineficientă cu afectarea uneia sau mai multor linii mieloide şi risc crescut de transformare în leucemie acută. Diagnosticul curent include morfologia sângelui periferic şi a măduvei, examenul citogenetic şi biopsia osteomedulară. Material și metodă. În acest studiu am analizat un lot de 33 de pacienți diagnosticați cu SMD cu risc scăzut (IPSS 0 şi intermediar-1) conform clasificării OMS 2001 în perioada 2008-2012. Diagnosticul s-a stabilit pe baza hemogramei, a examenului medular şi a examenului citogenetic. Au fost excluse alte cauze de citopenie sau modificări displazice secundare. Rezultate. Tipurile de SMD conform clasificării OMS pe lotul nostru de pacienți au fost: 9 cazuri de AR, 16 cazuri de ARSI, şi 8 cazuri de CRDM din care 2 cazuri CRDM-SI. Examenul citogenetic a fost efectuat la toți pacienții, dar numai la 25 de pacienți au fost obținute metafaze analizabile. Pacienții la care nu s-au obținut metafaze la examenul citogenetic au fost considerați cu risc scăzut dacă au avut o singură citopenie şi procentul de blaşti în măduvă a fost sub 5\%. Scorurile IPSS şi IPSS-R au fost calculate la pacienții la care s-au obținut metafaze analizabile la examenul cytogenetic şi s-au urmărit supraviețuirea şi evenimentele care au dus la deces. Conform scorului IPPS din 1997, examenul citogenetic a fost favorabil în 17 cazuri, intermediary întrun caz şi nefavorabil în 7 cazuri. Scorul IPSS a fost favorabil în 13 cazuri şi intermediar-1 în 12 cazuri. Conform IPSS$R$, examenul citogenetic a fost foarte favorabil şi favorabil în 17 cazuri, intermediar într-un caz, nefavorabil în 6 cazuri şi foarte nefavorabil în 1 caz. IPSS-R a fost cu risc foarte scăzut şi scăzut în 17 cazuri şi intermediar şi crescut în 8 cazuri. Concluzii. Aplicarea acestui nou scor IPSS-R tuturor pacienților la diagnostic ajută la aprecierea prognosticului, a riscului de transformare în leucemie acută şi a tratamentului. Singura terapie cu intenție curativă este allotransplantul de celule stem hematopoietice.

Cuvinte cheie: sindroame mielodisplazice, Sistemul de Scor Prognostic Internațional (IPSS), Sistemul de Scor Prognostic InternaționalRevizuit (IPSS-R)

Received: $4^{\text {th }}$ April 2013; Accepted: $31^{\text {st }}$ August 2013; Published: 14 ${ }^{\text {th }}$ September 2013.

\section{Introduction}

Myelodysplastic syndromes (MDS) are a group of heterogeneous clonal stem cell disorders characterized by ineffective hematopoiesis with dysplastic changes in one or more myeloid cell lines and increased risk of progression into acute leukemia. The current diagnosis criteria include the morphology of peripheral blood (PB) and bone marrow (BM) and cytogenetic exam. The clonal cytogenetic abnormalities were described in 40-60\% of cases $(1-4)$.

In 1997, Greenberg and his collaborators proposed the International Prognostic Scoring
System (IPSS) which had become the gold standard for patients with de novo MDS. It was useful for estimating the survival and risk of progression to acute leukemia (5). IPSS score uses the following parameters: the number of cytopenias, the percent of bone marrow blasts and karyotype (limited number of cytogenetic abnormalities). It classifies patients into four risk groups and enables the estimations for global survival and the risk of progression to acute leukemia.

In September 2012, Greenberg and his collaborators proposed a new Revised International Prognostic Scoring System (Revised International Prognostic Scoring System, R-IPSS) 
Table1. Distribution of MDS patients according to clinical variables

\begin{tabular}{|c|c|c|c|c|c|c|c|}
\hline \multirow[b]{2}{*}{ Variables } & \multirow[b]{2}{*}{$\begin{array}{c}\text { No. of } \\
\text { patients }(\%)\end{array}$} & \multirow[b]{2}{*}{ Died, no. $(\%)$} & \multirow[b]{2}{*}{$\begin{array}{l}\text { Average } \\
\text { survival } \\
\text { (months) }\end{array}$} & \multicolumn{2}{|c|}{ AML evolution } & \multicolumn{2}{|c|}{ Other causes of death } \\
\hline & & & & $\begin{array}{c}\text { No. of } \\
\text { patients }\end{array}$ & $\begin{array}{c}\text { Average } \\
\text { survival } \\
\text { (months) }\end{array}$ & $\begin{array}{l}\text { No. of } \\
\text { patients }\end{array}$ & $\begin{array}{l}\text { Average } \\
\text { survival } \\
\text { (months) }\end{array}$ \\
\hline Age $\leq 60$ years & $4(12.13 \%)$ & $1(3.03 \%)$ & 40 & 1 & 9 & 0 & - \\
\hline Age $>60$ years & $29(87.87 \%)$ & $10(30.30 \%)$ & 45 & 4 & 29.25 & 6 & 15 \\
\hline Female & $18(54.54 \%)$ & $8(24.24 \%)$ & 41.50 & 3 & 24.33 & 5 & 16.80 \\
\hline Male & $15(45.46 \%)$ & $3(9.09 \%)$ & 37.83 & 2 & 26.50 & 1 & 6 \\
\hline $\mathrm{Hb} \geq 10 \mathrm{~g} / \mathrm{dl}$ & $8(24.24 \%)$ & $1(3.03 \%)$ & 47.57 & - & - & 1 & 6 \\
\hline $\mathrm{Hb} 8-10 \mathrm{~g} / \mathrm{dl}$ & $15(45.45 \%)$ & $4(12.12 \%)$ & 39.09 & 2 & 11.50 & 2 & 27 \\
\hline $\mathrm{Hb}<8 \mathrm{~g} / \mathrm{dl}$ & $10(30.31 \%)$ & $6(18.18 \%)$ & 29 & 3 & 39.33 & 3 & 10 \\
\hline $\mathrm{ANC} \geq 0.8 \times 10^{3} / \mu \mathrm{l}$ & $33(100 \%)$ & $11(33.33 \%)$ & 39.95 & 5 & 25.20 & 6 & 15.33 \\
\hline ANC $<0.8 \times 10^{3} / \mu 1$ & $0(0 \%)$ & - & - & - & - & - & - \\
\hline $\begin{array}{c}\text { Platelets } \geq 100 \\
\times 10^{3} / \mu 1\end{array}$ & $29(87.87 \%)$ & $11(33.33 \%)$ & 36.77 & 5 & 25.20 & 6 & 15.33 \\
\hline $\begin{array}{l}\text { Platelets } 50-100 \\
\quad \times 10^{3} / \mu l\end{array}$ & $4(12.13 \%)$ & - & 45.25 & - & - & - & - \\
\hline $\begin{array}{c}\text { Platelets }<50 \\
\mathrm{x} 10^{3} / \mu \mathrm{l}\end{array}$ & $0(0 \%)$ & - & - & - & - & - & - \\
\hline $\begin{array}{l}\text { Bone marrow } \\
\text { blasts } 0-2 \%\end{array}$ & $17(51.52 \%)$ & $5(15.15 \%)$ & 43.75 & 3 & 34.33 & 2 & 14 \\
\hline $\begin{array}{l}\text { Bone marrow } \\
\text { blasts }>2-<5 \%\end{array}$ & $16(48.48 \%)$ & $6(18.18 \%)$ & 35.40 & 2 & 11.50 & 4 & 15.50 \\
\hline
\end{tabular}

$\mathrm{ANC}=$ Absolute neutrophil count

(6). It uses the following parameters: severity of cytopenias, the percent of medullary blasts and cytogenetic exam. This prognostic system contains a greater number of cytogenetic abnormalities and allows for a better classification of SMD patients according to risk groups.

In this study we aim to analyze the importance of a new prognostic scoring system in evaluating patients with low-risk myelodysplastic syndrome at diagnosis.

\section{Materials and methods}

Between 2008 and 2012, 33 patients with lower-risk MDS (IPSS 0 and intermediate-1) according to the WHO classification 2001, were observed. Informed consent was obtained for each patient and all investigations were conducted according with local and national ethical rules.
The patients were diagnosed in three Romanian Hematology Departments. The diagnosis was established based on blood cell counts, bone marrow (aspirate and biopsy) exam and cytogenetic exam. Other causes of cytopenias or dysplastic features were excluded. Some patients were evaluated at 6 months interval by bone marrow and cytogenetic exams. The patients who did not have analyzable metaphases were considered low risk if they had only one cytopenia and the percent of medullary blasts were less $5 \%$. The mean values of cytopenia were: $\mathrm{Hb}<10 \mathrm{~g} / \mathrm{dl}$, ANC $<1.8 \times 10^{3} / \mu$ l, and platelets $<100 \times 10^{3} / \mu$ l. For all patients who had analyzable metaphases at cytogenetic exam, the IPSS score, the survival and the death leading events were observed.

The cytogenetic exam was performed initially at diagnosis and then every 6 months. 
Table 2. The cytogenetic score and IPPS (1997)

\begin{tabular}{lccccccc}
\hline & $\begin{array}{c}\text { No. of } \\
\text { patients }(\%)\end{array}$ & \multicolumn{2}{c}{ No. patients alive } & \multicolumn{2}{c}{ AML evolution } & \multicolumn{2}{c}{ Other causes of death } \\
\cline { 3 - 7 } & & No. of & $\begin{array}{c}\text { Average } \\
\text { patients } \\
\text { survival } \\
\text { (months) }\end{array}$ & $\begin{array}{c}\text { No. of } \\
\text { patients }\end{array}$ & $\begin{array}{c}\text { Average } \\
\text { survival } \\
\text { (months) }\end{array}$ & $\begin{array}{c}\text { No. of } \\
\text { patients }\end{array}$ & $\begin{array}{c}\text { Average } \\
\text { survival } \\
\text { (months) }\end{array}$ \\
\hline $\begin{array}{l}\text { Cytogenetic examination } \\
\text { Good }\end{array}$ & $17(68 \%)$ & 14 & 36.42 & 2 & 32.5 & 1 & 31 \\
$\quad$ Intermediate (0.5) & $1(4 \%)$ & 1 & 47 & - & - & - & - \\
Poor (1) & $7(28 \%)$ & 5 & 43.2 & 1 & 44 & 1 & 16 \\
IPSS & $13(52 \%)$ & 10 & 38.1 & 2 & 32.5 & 1 & 31 \\
Low(0) & $12(48 \%)$ & 10 & 39.2 & 1 & 44 & 1 & 16 \\
Intermediate-1 (0.5-1) & & & & & & & \\
\hline
\end{tabular}

Bone marrow samples were cultured using overnight and synchronized culture and processed by conventional cytogenetic procedures with GTG banding. In each case, at least 15 metaphases were analyzed and the karyotype was described according to ISCN $2009(7,8)$. FISH exam for 5q- and monosomy 7 have not been performed.

Patients were reassessed with R-IPSS score and it was found that the new system allows a more accurate classification of patients according to the risk group.

Patients received treatment with red blood cells transfusion, erythropoiesis stimulating agents (ESA) or oversight. No patient received chemotherapy agents, hypomethylating agents or hematopoietic stem cell transplantation.

\section{Results}

Distribution according to age, gender, $\mathrm{Hb}$, absolute neutrophils count, platelets, bone marrow blasts are presented in Table 1.

The gender distribution was 15 men $(45.46 \%)$ and 18 women $(54.54 \%)$, sex ratio was $\mathrm{B}: \mathrm{F}=0.8: 1$ and the average age was of 72.36 years (varying between $43-82$ years).

The MDS classification according to WHO was as follows: 9 cases RA (27.27\%), 16 cases RARS (48.48\%), 8 cases RCMD of which 2 cases were RCMD-RS (24.24\%).
Analyzable metaphases at cytogenetic exam were obtained in 25 of 33 patients $(75.75 \%)$.

More than 2 cytogenetic exams were performed every 6 months for 14 patients (54\%). The proportion of metaphases was: RA in $44.44 \%$ (4 cases), RARS in $81.25 \%$ (13 cases) and RCMD in $100 \%$ (8 cases). In 8 patients, the cytogenetic exam did not show analyzable metaphases at the diagnosis and it was repeated subsequently.

According to IPSS, cytogenetic examination results (1997) were (Table 2):

Good prognosis (score 0) (normal,-y, del 5q, del(20q)) for 17 patients:

-normal-15 cases: 6 cases RARS, 4 cases RA, 4 cases RCMD, 1 case RCMD-RS

-y: 1 case RCMD-R

- del(20q)-1 case RARS

Intermediate prognosis (score 0.5): 1 case RCMD $(-4,+16)$

Poor prognosis (score 1) ( $\geq 3$ abnormalities- and/ or any abnormality of chromosome 7) for 7 patients:

-1 case RARS associated with monosomy 7

-6 cases with complex karyotype:

- 1 case RCMD: (del(22)(q13), del(5)(q13),$7,+5, \operatorname{del}(5 \mathrm{q})(\mathrm{q} 34))$

- 1 case RARS:del(18)(p11), del(12)(p12)

(1), del(11)(q11)

-1 case RARS: $\operatorname{del}(3)(\mathrm{p} 21),-12,+8$

-1 case RARS:del(5)(q31),-7 + 22 
Table 3. The cytogenetic score and R-IPSS (2012)

\begin{tabular}{|c|c|c|c|c|c|c|c|}
\hline & \multirow[b]{2}{*}{$\begin{array}{l}\text { No. patients } \\
(\%)\end{array}$} & \multicolumn{2}{|c|}{ Patients alive } & \multicolumn{2}{|c|}{ AML cause of death } & \multicolumn{2}{|c|}{ Other causes of death } \\
\hline & & $\begin{array}{c}\text { No. } \\
\text { patients }\end{array}$ & $\begin{array}{l}\text { Average } \\
\text { survival } \\
\text { (months) }\end{array}$ & $\begin{array}{c}\text { No. } \\
\text { patients }\end{array}$ & $\begin{array}{l}\text { Average } \\
\text { survival } \\
\text { (months) }\end{array}$ & $\begin{array}{c}\text { No. } \\
\text { patients }\end{array}$ & $\begin{array}{l}\text { Average } \\
\text { survival } \\
\text { (months) }\end{array}$ \\
\hline \multicolumn{8}{|l|}{ Cytogenetic examination } \\
\hline Very good $(0)$ & $1(4 \%)$ & 1 & 33 & - & - & - & - \\
\hline Good (1) & $16(64 \%)$ & 13 & 36.69 & 2 & 32.50 & 1 & 31 \\
\hline Intermediate (2) & $1(4 \%)$ & 1 & 47 & - & - & - & - \\
\hline Poor $(3)$ & $6(24 \%)$ & 5 & 43.20 & 1 & 44 & - & - \\
\hline Very poor (4) & $1(4 \%)$ & - & - & - & - & 1 & 16 \\
\hline \multicolumn{8}{|l|}{$R-I P S S$} \\
\hline Very low $(\leq 1.5)$ & $1(4 \%)$ & 1 & 57 & - & - & - & - \\
\hline Low $(2-3)$ & $16(64 \%)$ & 13 & 37.46 & 2 & 32.50 & 1 & 31 \\
\hline Intermediate (3.5-4.5) & $6(24 \%)$ & 5 & 34.40 & 1 & 44 & - & - \\
\hline $\operatorname{High}(5-6)$ & $2(8 \%)$ & 1 & 56 & - & - & 1 & 16 \\
\hline Very high $(>6)$ & $0(0 \%)$ & - & - & - & - & - & - \\
\hline
\end{tabular}

- 1 case RARS: del(5)(q22), $\operatorname{del}(4)(\mathrm{q} 25)$, $\operatorname{del}(4)(\mathrm{q} 34)$

- 1 case RARS: -17, del(3)(q27), del(4)(q31)

IPSS (1997) score classified patients in the following risk groups: 13 patients with low risk $(0)$ and 12 patients with intermediate risk 1 (0.5-1) (Table 2).

The R-IPSS score (2012) allowed patient's stratifying in five risk groups. According to R-IPSS (2012), cytogenetic exam results were (Table 3):

Very good prognosis (score 0) (-y, $\operatorname{del}(11 q))$ :-1 case of the RCMD-RS(-y)

Good prognosis (score 1) (normal, del(12p), del(20q), del(5q), a double containing anomalies (5q)) in 16 cases:

-1 case of RARS with del(20q)

-15 cases with normal karyotype: 6 cases of RARS, 4 cases RCMD, 1 case of RCMD-RS and 4 cases RA

Intermediate prognosis (score 2) $(\operatorname{del}(7 q),+8,+19, \mathrm{i}(17 q)$, any other anomaly or anomalies of 2 independent clones): 1 case, RCMD: $-4,+16$

Poor prognosis (score 3) (-7, $\operatorname{inv}(3) / t(3 q) / \operatorname{del}(3 q)$, containing double- $7 / \operatorname{del}(7)$ (q), complex karyotype with 3 abnormalities): 6 cases:

- 1 case RARS:-17, del(3)(q27), del (4)(q31)

- 1 case RARS:del(3)(p21), $-12,+8$

- 1 case RARS: $\operatorname{del}(18)(\mathrm{p} 11), \operatorname{del}(12)$ (p12), del(11)(q11)

- 1 case RARS:del(5)(q31), $-7+22$

- 1 case RARS: -7

- 1 case RARS-del(5)(q22), $\operatorname{del}(4)$ (q25), del(4)(q34).

Very poor prognosis (score 4) (complex karyotype > 3 abnormalities): 1 case CRDM (>3 complex karyotype abnormalities) associated with $\operatorname{del}(22)(q 13), \operatorname{del}(5)(q 13),-7,+5, \operatorname{del}(5)(q 34)$.

R-IPSS score depends on the cytogenetic score, marrow blasts percentage and depth of cytopenias (Table 3). R-IPSS (2012) score classified patients in the following risk groups:1 patient with very low risk, 16 patients with low risk, 6 patients with intermediate risk and 2 patients with high risk (Table 3).

The classification in risk groups according R-IPSS and WHO classification is presented in Table 4.

The distribution of patients according to cytogenetic IPSS and R-IPSS is presented in 
Table 4. The classification in risk groups according R-IPSS score and WHO classification

\begin{tabular}{lcccccc}
\hline \multirow{2}{*}{$\begin{array}{c}\text { Risk categories } \\
\text { (years survival) }\end{array}$} & Score & \multicolumn{5}{c}{ No. patients } \\
\cline { 3 - 7 } & & RARS & RA & RCMD & RCMD-RS & Total \\
\hline Very low (8.8y) & $\leq 1.5$ & 1 & - & - & - & 1 \\
Low (5.3 y) & $2-3$ & 6 & 4 & 5 & 1 & 16 \\
Intermediate (3 y) & $3.5-4.5$ & 4 & - & 1 & 1 & 6 \\
High (1.6 y) & $5-6$ & 2 & - & - & - & 2 \\
Very high (0.8 y) & $>6$ & - & - & - & - & 0 \\
\hline
\end{tabular}

Table 5. The distribution of cases depending on cytogenetic IPSS and cytogenetic R-IPSS

\begin{tabular}{cccccccc}
\hline & & \multicolumn{3}{c}{ CYTOGENETIC RISK - R-IPSS, no. cases (\%) } \\
\cline { 3 - 7 } & & $\begin{array}{c}\text { Very } \\
\text { good }\end{array}$ & Good & Intermediate & Poor & $\begin{array}{c}\text { Very } \\
\text { poor }\end{array}$ & Total \\
\hline & Good & 1 & 16 & $0(0 \%)$ & $0(0 \%)$ & $0(0 \%)$ & 17 \\
$(100 \%)$ & $(100 \%)$ & & $08 \%)$ \\
CYTOGENETIC & Intermediate & $0(0 \%)$ & $0(0 \%)$ & $1(100 \%)$ & $0(0 \%)$ & $0(0 \%)$ & $1(4 \%)$ \\
RISK - IPSS & Poor & $0(0 \%)$ & $0(0 \%)$ & $0(0 \%)$ & 6 & 1 & 7 \\
& & & & $(100 \%)$ & $(100 \%)$ & $(28 \%)$ \\
\hline
\end{tabular}

Table 6. The distribution of patients according to the IPPS and R-IPSS

\begin{tabular}{cccccc}
\hline & & \multicolumn{3}{c}{ R-IPSS } \\
\cline { 3 - 6 } & & Very low & Low & Intermediate & High \\
\hline \multirow{3}{*}{ IPSS } & Low, $\mathrm{n}=13$ & $1(100 \%)$ & $12(75 \%)$ & $0(0 \%)$ & $0(\%)$ \\
& Intermediate, $\mathrm{n}=12$ & $0(0 \%)$ & $4(25 \%)$ & $6(100 \%)$ & $2(100 \%)$ \\
& TOTAL & $1(100 \%)$ & $16(100 \%)$ & $6(100 \%)$ & $2(100 \%)$ \\
\hline
\end{tabular}

Table 5. The distribution of patients according to IPSS and R-IPSS is presented in Table 6.

In our group, the karyotype was normal in 15 out of 25 patients $(64.64 \%)$ and cytogenetic abnormalities were present in $36 \%$ of cases. Three patients with normal karyotype had an average survival of 30.3 months and thirteen patients had a follow-up of 36.7 months.

In our group, one case with RCMD-RS lost the $y$ chromosome and is alive after 33 months.

In our group, there was one case of RCMD with intermediate prognosis $(-4+16)$ and follow-up of 44 months.

In our study, one case of RA at diagnosis had no analyzable metaphases and trans- formed into AML in 6 months. The cytogenetic exam at six months showed the +8 . The survival was nine months.

In this lot, it was a case of RARS with -7, with an observation period of 12 months.

Del $5 q$ is the most common abnormality described in MDS, appearing in more than $30 \%$ of cases $(9,11)$. For this lot, there were no cases of isolated abnormalities described. There have been two cases of del (5q) within the complex karyotype (RARS, RCMD), in both cases associated with monosomy 7 . The observation period of those patients was 48 months.

One case with complex karyotype who presented 3 abnormalities including $\operatorname{del}(5)$ 
Table 7. Average and median survival

\begin{tabular}{|c|c|c|c|c|c|c|c|}
\hline \multicolumn{4}{|c|}{ Media } & \multicolumn{4}{|c|}{ Median } \\
\hline \multirow[b]{2}{*}{ Estimate } & \multirow[b]{2}{*}{ Std. Error } & \multicolumn{2}{|c|}{ 95\% Confidence Interval } & \multirow[b]{2}{*}{ Estimate } & \multirow[b]{2}{*}{ Std. Error } & \multicolumn{2}{|c|}{ 95\% Confidence Interval } \\
\hline & & $\begin{array}{l}\text { Lower } \\
\text { Bound }\end{array}$ & $\begin{array}{l}\text { Upper } \\
\text { Bound }\end{array}$ & & & $\begin{array}{l}\text { Lower } \\
\text { Bound }\end{array}$ & $\begin{array}{l}\text { Upper } \\
\text { Bound }\end{array}$ \\
\hline 19.636 & 4.762 & 10.303 & 28.970 & 15.000 & 3.853 & 7.447 & 22.553 \\
\hline
\end{tabular}

Table 8. Causes of death

\begin{tabular}{|c|c|c|c|c|c|}
\hline \multirow[b]{2}{*}{ Diagnosis } & \multirow[b]{2}{*}{ No. of deaths } & \multicolumn{2}{|c|}{ Sore } & \multirow{2}{*}{$\begin{array}{l}\text { Average } \\
\text { survival } \\
\text { (months) }\end{array}$} & \multirow[b]{2}{*}{ Cause of death } \\
\hline & & IPSS & R-IPSS & & \\
\hline RARS & 1 & 0 & 2.5 & 50 & AML \\
\hline RARS & 1 & 0 & 3 & 31 & Infection \\
\hline RARS & 1 & 1 & 4.5 & 44 & AML \\
\hline RARS & 1 & 1 & 5.5 & 16 & Infection \\
\hline RCMD & 1 & 0 & 3 & 15 & AML \\
\hline RARS & 2 & - & - & $12.5(2-23)$ & \\
\hline RA & 4 & - & - & $8.7(6-12)$ & - \\
\hline
\end{tabular}

(q22), del(4)(q25), del(4)(q34) had an average survival of 16 months followed by septic death.

In two cases of RARS and a case of RCMD with complex karyotype, there have been cytogenetic improvements. These patients received treatment with erythropoiesis stimulating agents (ESA). For a RCMD case, cytogenetic examination at the diagnosis showed: $(\operatorname{del}(22)(\mathrm{q} 13)$, $\operatorname{del}(5)(q 13),-7,+5, \operatorname{del}(5)(q 34))$ and 6 months later the values were normal (46, XX (16)). In a case of RARS, the cytogenetic exam at diagnosis showed:-17, del(3)(q27), del(4)(q31), and after 6 month evaluation noted the absence of chromosome Y. In a case of RARS with complex cytogenetic diagnosis $\operatorname{del}(5)(\mathrm{q} 31)-7,+22$, evaluation at 12 months showed monosomy 15 .

Eleven deaths occurred during observation period ( 4 cases RA, 6 cases RARS, 1 case RCMD) and the IPSS score in 5 patients was estimated. Average survival was 19 months with $95 \%$ CI between 10 and 28 months (Table 7). Survival Kaplan Meier curve of eleven patients with lower risk according to IPSS is presented in Figure 1.
The causes of death were (Table 8):

- progression to AML (5 cases): 2 cases of RA, 2 cases of RARS and 1case of RCMD (45.45\%)

- infection (4 cases): 1 case of RA and 3 cases of RARS $(36.36 \%)$

- other causes ( 2 cases): 1 case of RA and 1 case of RARS (18.18\%)

\section{Discussion}

This study contains a small number of patients with low-risk MDS (low and intermediate 1 IPSS) who were evaluated by cytogenetic exam at diagnosis and every six months. The recruitment of patients started in April 2008 and the follow-up period is too short to asses overall survival.

The cohort included 15 men and 18 women, the sex ratio $\mathrm{M}: \mathrm{F}=0.8: 1$, median age 72.36 years (varying 45-80 years). Greenberg and col. have published results of 7012 patients lot with average age of 71 years (mostly over 60 years of age) $(77 \%)$ with predominance of the male sex $(\mathrm{M}: \mathrm{F}$ ratio $=1.5: 1)(6)$. 


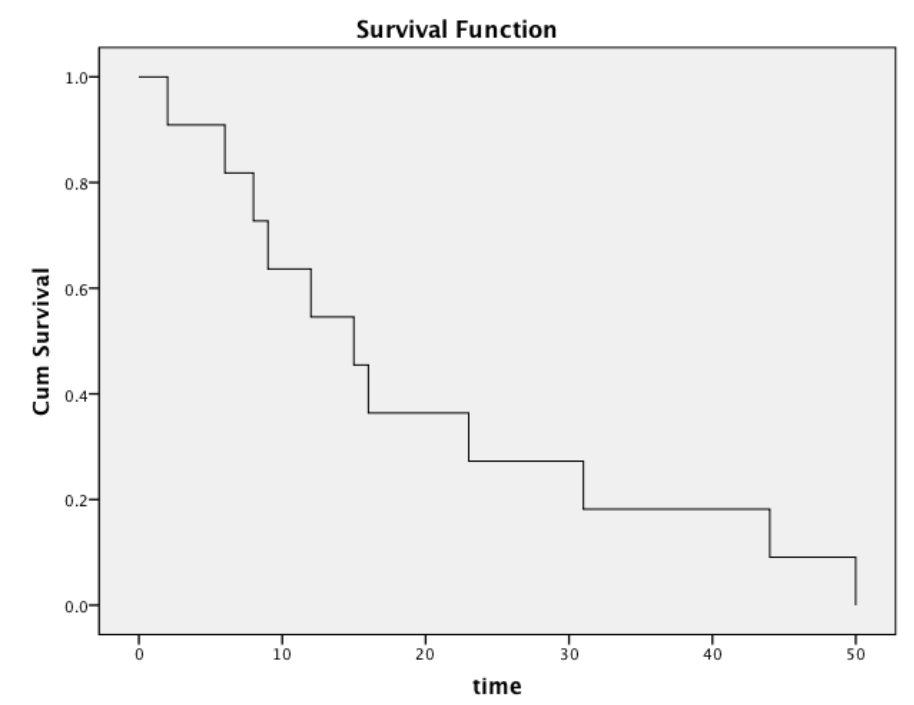

Figure 1. Survival Kaplan Meier curve of eleven patients with lower risk according to IPSS.

ten associated with progression to AML. In $32 \%$ of cases, it occurs as a complex karyotype most commonly associated with del $5 \mathrm{q}$, with a median survival of 17 months (10).

Haase described a median survival of 8.3 months in patients with monosomy 7 in a complex karyotype and 14 months in patients with isolated anomaly (10).

According to IPSS score, median survival is $0.8-1.7$ years (5). In the patients with complex karyotype, median survival is 8.7 months (9). One case had no analyzable metaphases on cytogenetic examination.

In this group, 17 patients with good cytogenetic risk according IPSS, the R-IPSS score reassessed one case as very good and

In this study, 15 patients $(60 \%)$ had normal karyotype, 6 patients $(24 \%)$ had complex karyotype, one patient with loss of y chromosome, one patient with monosomy 7 , one patient with del20q. and no patient with isolated del5q only within complex karyotype.

In medical literature, cytogenetic abnormalities are described in $40-60 \%$ of patients (4). The most common chromosomal abnormalities described in literature are: $+8,-5,-7,-y$, del. of long arm of chromosome 5, 7, 11, 13, 20. Complex karyotype ( $\geq 3$ abnormalities) occurs in $15 \%$ of patients (9).

The patients with normal karyotype have a median survival of 57 months (10).

The absence of the $y$ chromosome in MDS is associated with good prognosis in IPSS score and very good in R-IPSS score. Haase and Cooper describe a 36 month median survival in patients with $-\mathrm{y}$ and del $20 \mathrm{q}$ in $3.6 \%$ in cases with a median survival 71 months (10).

In medical literature, Haase describes + 16 associated with a survival of 44 months in a non-complex karyotype (10). Trisomy 8 is described $12-25 \%$ of cases of MDS (10) and is of-
16 cases as good risk group. Seven patients with poor cytogenetic risk according IPSS, RIPSS score reassessed them as poor and very poor cytogenetic risk group (Table 5).

Thirteen patients with low risk according IPSS, the R-IPSS score reassessed one case as very low risk and 12 cases as low risk. Twelve patients with intermediate risk according IPSS, R-IPSS score assessed 4 cases as low-risk, 6 cases as intermediate-risk and 2 cases as high-risk (Table 6).

The deaths occurred in 11 patients from 33 patients (33.33\%). Median survival was 19.6 (2-50 months). The main cause of death was AML progression ( $45.45 \%$ ), followed by infections.

All patients included in this study were IPSS low and intermediate-1. In medical literature, patients with low or intermediate-1 IPSS have a median survival of 5.7 and 3.5 years respectively (5).

Application of the IPPS-R score has allowed a better classification of these patients; in one case, the score was intermediate (4.5) with a survival of 44 months and in one case the score was high risk (5.5). He died at 16 months from diagnosis through infection and presented a complex karyotype (> 3 chromosomal abnormalities). 


\section{Conclusions}

Cytogenetic exam is an important prognostic factor for MDS patients, being able to estimate the overall survival and the risk of progression to acute leukemia. Cytogenetic exam is recommended at diagnosis and whenever there is a suspicion of disease progression. Cytogenetic abnormalities are very heterogeneous in MDS and the importance of some abnormalities is still unknown. The small number of patients and the short surveillance time do not allow an assessment of survival and of the risk of transformation into acute leukemia. In three cases, an improvement in transfusions had an impact on cytogenetic abnormalities. In two of three cases, the survival was longer than 48 months from diagnosis and one case died at 44 months with secondary acute leukemia. R-IPSS score is more complex and evaluates the deepness of cytopenias ( $\mathrm{Hb}$, neutrophils and platelets), the percentage of bone marrow blasts in low risk MDS has been divided into two different prognostic groups (0-2 \% and 2-5\%) and cytogenetic abnormalities are better described. More cytogenetic abnormalities (15 compared to 6 in IPSS) are described. The score's evaluation at diagnosis, especially in young patients, gives prognosis value and assesses the risk of transformation into acute leukemia. The only therapeutic option with curative intent for high-risk patients is allogeneic bone marrow transplantation. It is recommended within the first year after diagnosis to avoid iron overload due to blood transfusions (11).

Although according to IPSS score (1997) all patients were evaluated as low risk (0.5-1), the new score allows a more accurate classification of patients and eight patients were evaluated as intermediate and high risk.

\section{Acknowledgment}

This work was supported by the grant PN 41-087 / 2007 from the Romanian Ministry of Research and Technology. The authors express the gratitude to European LeukemiaNet for their permanent support.

\section{References}

1. Bennett JM, Catovsky D, Daniel MT, Flandrin G, Galton DA, Gralnick HR, et al. Proposals for the classification of the myelodysplastic syndromes. Br J Haematol, 1982, 51:189-199.

2. Cazzola M, Malcovati L: Myelodysplastic syndromes -coping with ineffective hematopoiesis. N Engl J Med, 2005, 352: 536-538.

3. Vardiman JW, Harris NL, Brunning RD: The new World Health Organization classification of myeloid neoplasms: Blood, 2002, 100:2292-2302.

4. Fenaux P: Myelodysplastic syndromes: from pathogenesis and prognosis to treatment. SeminHematol., 2004;41:6-12.

5. Greenberg P, Cox C, LeBeau MM, Fenaux P, Morel P, Sanz G: International Scoring System for Evaluating Prognosis in Myelodysplastic Syndromes. Blood, 1997; 89:2079-2088.

6. Greenberg P, Tuechler H, Schanz J, Sanz G, Solé F, Bennett $\mathrm{J}$ et al: Revised International Prognostic Scoring System for Myelodysplastic Syndromes. Blood, 2012 120: 2454-2465.

7. Swansbury J: Methods in Molecular Biology TMCancer Cytogenetics Methods and Protocols.Humana, 2003;220: 43-56.

8. Shaffer LG, Slovak ML, Campbell JL: An International System for Human Cytogenetic Nomenclature, 2009.

9. Nowell PC. Chromosome abnormalities in myelodysplastic syndromes. SeminOncol, 1992;19:1925-1929.

10. Haase D, Germing U, Schanz J, Pfeilstöcker M, Nösslinger T, Steidl N: New insights into the prognostic impact of the karyotype in MDS andcorrelation with subtypes: evidence from a core dataset of 2124 patients. Blood 2007, 110: 4385-4395

11. De Witte T, Hermans J, Vossen J, Bacigalupo A., Meloni G., Jacobsen N. et al:Haematopoietic stem cell transplantation for patients with myelodysplastic syndromes and secondary acute myeloid leukemias: A report on behalf of the Chronic Leukaemia Working Party of the European Group for Blood and Marrow Transplantation (EBMT).Br J Haematol,2000;110:620-630. 